Elżbieta Ostrowska

Katedra Bankowości

Uniwersytet Gdański

Marta Deryło

Studia Doktoranckie Wydziału Zarządzania

Uniwersytet Gdański

\title{
Determinanty rozwoju rynku emisji pierwotnych akcji na Giełdzie Papierów Wartościowych w Warszawie
}

\section{Streszczenie}

$\mathrm{W}$ artykule zdefiniowano termin emisje pierwotne akcji, dokonano identyfikacji i klasyfikacji determinant rozwoju rynku emisji pierwotnych akcji na Giełdzie Papierów Wartościowych w Warszawie. Determinanty podzielono na te związane z funkcjonowaniem spółki oraz na te związane z jej otoczeniem. Na podstawie wskazanych przez autorów kryteriów dokonano również analizy tendencji na rynku emisji pierwotnych akcji. Za kryteria te uznano rodowód spółek debiutujących na rynku, zależność od indeksu WIG, przyrost kapitalizacji, liczbę wycofań spółek z giełdy, przyrost liczby rachunków inwestycyjnych, a także PKB.

Słowa kluczowe: emisje pierwotne akcji, IPO, giełda, debiut.

\section{Wprowadzenie}

Emitowanie akcji pierwotnych przez przedsiębiorstwo postrzegane jest jako kolejny krok w jego rozwoju. Wejście na giełdę papierów wartościowych umoż- 
liwia dostęp do źródeł finansowania działalności spółki, które są niedostępne dla przedsiębiorstw nienotowanych na niej. Zjawisko to wiąże się jednak z wieloma wyzwaniami i zagrożeniami. Podjęcie decyzji o debiucie na parkiecie giełdowym determinowane jest zatem przez wiele czynników wewnętrznych i zewnętrznych w stosunku do spółki. Celem niniejszego artykułu jest identyfikacja i klasyfikacja determinant rozwoju rynku emisji pierwotnych akcji, a także analiza tendencji na tym rynku.

\section{Definicja emisji pierwotnej akcji}

Emisja pierwotna zwana jest inaczej pierwszą ofertą publiczną (Initial Public Offering - IPO). Zgodnie z art. 4, pkt. 5. Ustawy o ofercie publicznej i warunkach wprowadzania instrumentów finansowych do zorganizowanego systemu obrotu oraz o spółkach publicznych pod tym terminem należy rozumieć „dokonaną po raz pierwszy ofertę publiczną dotyczącą określonych papierów wartościowych".

Z ofertą taką można się zetknąć, gdy przedsiębiorstwo podejmuje decyzję o wejściu na giełdę. $Z$ tego względu określane są one również mianem emisji „bez przeszłości” (unseasoned new issue). Wszystkie emisje pierwotne uznawane są za oferty pieniężne, ponieważ w zamian za środki pieniężne inwestor nabywa prawa o charakterze majątkowym i niemajątkowym do współwłasności spółki.

Z IPO wiąże się termin SPO (Secondary Public Offering). Oznacza on wprowadzenie do obrotu giełdowego akcji, które wcześniej były w posiadaniu spółki, ale zostały skierowane do nowych akcjonariuszy [Migracja kapitału... 2009, s. 269]. W niniejszym artykule IPO rozumiane będzie jako emisja akcji przedsiębiorstwa nienotowanego wcześniej na giełdzie.

\section{Klasyfikacja determinant rozwoju rynku emisji pierwotnych w Polsce}

\subsection{Uwagi wstępne}

Podejmując decyzję o debiucie na giełdzie, zarząd przedsiębiorstwa kieruje się potencjalnymi korzyściami, jakie może osiągnąć z tego tytułu. Rozważa

\footnotetext{
1 Oferta publiczna to przekazanie informacji o papierach wartościowych i warunkach ich zakupienia gronu co najmniej 150 osób lub nieoznaczonemu adresatowi. Ustawa nie narzuca formy ani sposobu przekazywania tych informacji, jednakże ich zakres powinien być wystarczający do podjęcia decyzji o zakupie papierów wartościowych [Ustawa z dnia 29 lipca 2005 r. o ofercie publicznej... art. 3].
} 
także szanse i zagrożenia związane z tą decyzją. Przedsiębiorstwa nie funkcjonują jednak w próżni, lecz w konkretnym otoczeniu społeczno-gospodarczym, które warunkuje nie tylko sposób prowadzenia działalności gospodarczej, ale i osiągane wyniki. Środowisko to ma wpływ na decyzje kierownictwa podmiotu o wyborze właściwego momentu jego wejścia na giełdę.

W związku z tym można wyróżnić następujące determinanty debiutów spółek na giełdzie papierów wartościowych:

1) determinanty związane z otoczeniem spółki: makroekonomiczne, wynikające z koniunktury giełdowej, behawioralne;

2) determinanty związane $z$ funkcjonowaniem spółki i będące wyznacznikiem:

- szans dla rozwoju spółki: większy dostęp do źródeł kapitału, efekty marketingowe, nabywanie lub łączenie się z przedsiębiorstwami notowanymi na giełdzie, obiektywna wycena spółki, zmiany w sposobie zarządzania,

- zagrożeń dla rozwoju spółki: koszty przygotowania i przeprowadzenia emisji pierwotnej, obowiązki związane z wymogami informacyjnymi, ryzyko utraty kontroli nad spółką, ryzyko niepowodzenia emisji akcji.

\subsection{Determinanty związane z otoczeniem spółki}

\section{Determinanty makroekonomiczne}

Sytuację gospodarczą w danym państwie ocenić można za pomocą kilku zmiennych: produktu krajowego brutto (PKB), stopy bezrobocia, inflacji oraz stopy procentowej [Samuelson i Nordhaus 2004, s. 8].

Produkt krajowy brutto to syntetyczny miernik efektów gospodarczych. Określa on łączną wartość dóbr i usług wytworzonych na terenie danego kraju w ciągu roku. Traktowany jest jako wyznacznik wielkości gospodarki. Wykorzystuje się go do oceny stanu gospodarki i fazy cyklu koniunkturalnego, w jakiej się ona znajduje.

$\mathrm{Z}$ wysokim wzrostem $\mathrm{PKB}$ z reguły związana jest niska stopa bezrobocia. Ma to miejsce $\mathrm{w}$ okresie dobrej koniunktury gospodarczej i działa pozytywnie na podejmowanie decyzji inwestycyjnych oraz skłonność do debiutów na giełdzie.

Wysoka inflacja postrzegana jest jako zjawisko niekorzystne i ma bezpośredni wpływ na kształtowanie się rynkowych stóp procentowych. Z kolei stopa procentowa wyznacza w gospodarce cenę pieniądza. Jej wzrost oznacza wyższe koszty związane z pozyskaniem zewnętrznego źródła finansowania, np. kredytu. Warto zwrócić uwagę na zależność występującą pomiędzy wysokością stopy procentowej a ryzykiem związanym $\mathrm{z}$ daną formą aktywności inwestorów i spółek.

Sytuacja makroekonomiczna i polityczna danego państwa ma wpływ na klimat inwestycyjny związany z emisjami papierów wartościowych na giełdzie. 
W tym kontekście dużą rangę ma analiza systemu podatkowego, która przekłada się na ocenę, czy państwo sprzyja rozwojowi przedsiębiorstw, czy też nie. Ponadto konstrukcja systemu podatkowego może przyciągać potencjalnych inwestorów na rynek kapitałowy np. poprzez niskie opodatkowanie zysków osiąganych na giełdzie. Z kolei zachodzące procesy globalizacji i integracji poszczególnych gospodarek sprawiły, że globalny klimat inwestycyjny wpływa na aktywność i nastroje inwestorów na rynku krajowym.

Dobra sytuacja gospodarcza kraju często przekłada się na lepsze wyniki finansowe osiągane przez przedsiębiorstwa, a także sprzyja planowaniu i podejmowaniu inwestycji. Wobec tego czynniki makroekonomiczne w istotny sposób determinują liczbę debiutów na giełdzie. Najwięcej emisji pierwotnych można zaobserwować bowiem w latach, w których występowała korzystna sytuacja gospodarcza. W sprzyjających warunkach relatywnie łatwiej jest pozyskać kapitał ze sprzedaży emisji akcji na rozwój działalności, a zatem prawdopodobieństwo wejścia na giełdę zakończonego sukcesem jest wyższe.

\section{Determinanty wynikające z koniunktury gietdowej}

Wśród czynników wpływających na koniunkturę giełdową wymienić można makroekonomiczne, finansowe związane z konkurencyjnymi źródłami dopływu kapitału, psychologiczne, a także demograficzne związane głównie ze strukturą wiekową i płcią potencjalnych inwestorów. Koniunktura ta mierzona jest za pomocą indeksów giełdowych, które wskazują tendencje panujące na rynku. Interesujące badania empiryczne w zakresie zależności pomiędzy procesami makroekonomicznymi ${ }^{3}$ a indeksem WIG przeprowadzili P. Fiszeder i S. Rowiński [Fiszeder i Rowiński 2012, s. 153-166]. Wykazali oni, że pomiędzy badanymi zmiennymi występuje zarówno krótko-, jak i długookresowa relacja. Jednak na podstawie przeprowadzonych przez nich badań można uznać, że badane czynniki makroekonomiczne nie wykazują znaczącego oddziaływania na zmiany cen akcji na giełdzie warszawskiej w krótkim okresie.

Z kolei tendencje występujące na giełdzie wpływają na sytuację gospodarczą kraju. Z badań przeprowadzonych przez J. Stąpałę wynika, że zmiany WIG wyprzedzały zmiany PKB średnio o ponad jeden kwartał $(1,12)$ [Stąpała 2012, s. 371].

Jednym z mierników umożliwiających ocenę sytuacji na giełdzie jest wskaźnik Market-to-Book (MTB), który pokazuje relację wartości rynkowej do

${ }^{2}$ Za sukces należy uważać efektywne zakończenie procedur emisji akcji, zgromadzenie zakładanej lub większej ilości kapitału z emisji oraz wzbudzenie zainteresowania emisją akcji wśród akcjonariuszy i drobnych inwestorów.

${ }^{3}$ Badaniem objęto następujące procesy makroekonomiczne: PKB, podaż pieniądza, poziom inflacji i wartość indeksu CRB. 
wartości księgowej spółki. Jego wysokie wartości mogą oznaczać przewartościowanie przedsiębiorstw i świadczyć o tym, że inwestorzy dostrzegają możliwości rozwoju danego sektora. W takiej sytuacji szanse podmiotów na udane wejście na giełdzie zwiększają się, ponieważ relatywnie łatwiej jest pozyskać inwestorów. Natomiast w przypadku występowania zjawiska niedowartościowania spółek, czyli niskiego wskaźnika MTB, przedsiębiorstwa rzadziej decydują się na debiut, co związane jest z obawami o niższą wycenę ich emisji. Wobec tego korzystna sytuacja na giełdzie zwiększa zainteresowanie potencjalnych inwestorów nabywaniem akcji, ale też i przedsiębiorstw rozważających decyzję o wejściu na giełdę.

\section{Determinanty behawioralne}

Ryzyko jest nieodłącznym elementem inwestowania. Powoduje ono występowanie niepewności i lęku przed poniesieniem strat przez inwestorów, którzy wykazują do nich silną awersję. Sprawia to, że straty są odczuwane w sposób bardziej dotkliwy niż radość z osiąganych zysków [Czerwonka i Rzeszutek 2012, s. 117]. Ponadto między kierownictwem przedsiębiorstwa a akcjonariuszami występuje nierównomierny dostęp do informacji. Zatem decyzje inwestycyjne obecnych i potencjalnych akcjonariuszy podejmowane są pod wpływem emocji, co widoczne jest na giełdzie w postaci „efektu tłumu”. Efekt ten jest wynikiem tego, że podejmując decyzje, inwestorzy nie kierują się racjonalną oceną inwestycji, ale trendem występującym na rynku. Jednak „tłum” zazwyczaj się myli. Determinanty behawioralne zatem to wszystkie zjawiska o podłożu psychologicznym, a nawet neurobiologicznym, towarzyszące podejmowaniu decyzji i mające na nie wpływ. Są one związane nie tylko z zachowaniami samych inwestorów, ale również z zachowaniami rynków papierów wartościowych [Ostrowska 2014, s. 185]. W związku z tym istotne znaczenie dla rozwoju rynku emisji pierwotnych akcji zyskuje perspektywa behawioralno-medioznawcza [Gackowski 2013, s. 177-209].

Pozytywne nastawienie inwestorów do nabywania kolejnych akcji umożliwia łatwiejsze uplasowanie na rynku akcji nowej spółki. Inwestorzy nabywają bowiem akcje, licząc na osiągnięcie zysków. Ponadto w początkowych latach funkcjonowania giełdy największy przyrost liczby rachunków inwestycyjnych występował w latach, w których odnotowano największą liczbę debiutów.

\subsection{Determinanty związane $\mathrm{z}$ funkcjonowaniem spółki}

\section{Determinanty będace wyznacznikiem szans na rozwój przedsiębiorstwa}

Dostęp do źródeł kapitału umożliwia przedsiębiorstwu rozwój. Może ono realizować plany inwestycyjne, a przez to wzmacniać swoją pozycję rynkową. 
O wyborze źródła finansowania $\mathrm{z}$ reguły decyduje jego dostępność i koszty z nim związane. Przeprowadzając emisję pierwotną akcji, możliwe jest zgromadzenie środków na działalność rozwojową zwłaszcza w przypadku, gdy spółka ma trudności z pozyskaniem finansowania z innych źródeł. Wejście na giełdę stwarza również możliwości pozyskiwania kapitału w drodze emisji obligacji lub commercial papers [Nawrot 2006, s. 162].

Obecność spółki na giełdzie wiąże się także z jej większą rozpoznawalnością. Spełnienie rygorystycznych warunków dopuszczających przedsiębiorstwo do publicznego obrotu sprawia, że w porównaniu z innymi podmiotami jest ono postrzegane jako bardziej wiarygodne. Ponadto kampania informacyjno-promocyjna towarzysząca wprowadzeniu spółki na giełdę umożliwia zbudowanie jej prestiżowego wizerunku nie tylko w odczuciu potencjalnych inwestorów, ale i klientów oraz kontrahentów. Jest to okazja do promocji, która właściwie wykorzystana może przynieść efekty w postaci zwiększenia rynków zbytu [Siwek 2005, s. 17; Nawrot 2006, s. 162].

Emisja akcji może być również wykorzystana jako sposób nabycia lub połączenia się ze spółką notowaną na giełdzie. Połączenie się dwóch przedsiębiorstw obecnych na giełdzie może zostać przeprowadzone np. w drodze wymiany akcji. Natomiast w przypadku przejmowania innego podmiotu najczęściej stosuje się dwie metody przejęcia [Nawrot 2006, s. 166]:

- akcje jednostki przejmowanej są umarzane, a jej właściciele otrzymują akcje przedsiębiorstwa przejmującego,

- właściciele spółki przejmowanej otrzymują akcje przedsiębiorstwa przejmującego, a następnie odsprzedają je bankowi inwestycyjnemu.

W przypadku zawierania powyższych transakcji bardzo istotna staje się kwestia wyceny podmiotu. Podstawą wyceny są rynkowe ceny akcji ustalane podczas sesji giełdowych jako wynik transakcji kupna - sprzedaży akcji. Ceny te wynikają z kształtowania się popytu i podaży i są wyznacznikiem wartości kapitału danego przedsiębiorstwa ${ }^{4}$.

Wejście spółki na giełdę jest także okazją do zmiany systemu zarządzania. W motywacyjnych systemach wynagradzania można wykorzystać odniesienie do kursu akcji, co ma zachęcić pracowników do długoterminowego patrzenia na przedsiębiorstwo, a także przyciągnąć do spółki wysokiej klasy specjalistów i zatrzymać ich. Byłoby to niemożliwe w sytuacji pozostawania podmiotu poza giełdą [Strategies... 2012, s. 5].

${ }^{4}$ Pomiędzy wycenami dwóch przedsiębiorstw charakteryzujących się identycznymi wskaźnikami ekonomiczno-finansowymi, z których jedno jest notowane na giełdzie, występuje różnica 10-15\% z korzyścią dla notowanej [Duszek 2010, s. 9]. 
Determinanty będące wyznacznikiem zagrożeń dla rozwoju przedsiębiorstwa

Koszty związane z przygotowaniem i przeprowadzeniem emisji pierwotnej akcji mają istotny wpływ na podjęcie decyzji o debiucie. Dzielą się one na trzy grupy:

- opłaty sądowe i administracyjne - dotyczą procedur dopuszczenia na rynek,

- wynagrodzenia doradców i gwarantów emisji,

- promocja oferty.

Część ponoszonych kosztów ma jednak charakter jednorazowy i nie występuje przy następnych emisjach. Wysokość kosztów wprowadzenia spółki na giełdę zależy od wysokości pozyskanego kapitału i waha się w granicach 5-7\% wartości kapitału dla średniej wielkości emisji. Nakłady te należy porównać z kosztami pozyskania kapitału z innych źródeł lub kosztami związanymi z zaniechaniem planowanych inwestycji [Duszek 2010, s. 11]. Innym kosztem, który musi rozważyć kierownictwo przedsiębiorstwa, są dochody, jakich oczekują inwestorzy w zamian za zakup akcji. Dochody te zależą od oczekiwanej przez nich stopy zwrotu z akcji po debiucie - im jest ona wyższa, tym większy jest koszt pozyskiwania kapitału w drodze emisji akcji [Nawrot 2006, s. 170].

Ponadto spółki ponoszą również wydatki związane ze spełnieniem ciążących na nich obowiązków informacyjnych. Koszty te dotyczą przygotowywania raportów bieżących i okresowych oraz ponoszenia kar za zatajenie lub podanie niezgodnych z rzeczywistością informacji, jak również za nieterminowe ich przedstawienie. Obowiązki informacyjne wymuszają przekazywanie informacji, które do tej pory spółka mogła zachowywać w tajemnicy, np. plany związane z rozwojem. Wiążą się z tym obawy, że konkurencja będzie mogła wykorzystać te wiadomości do poprawy swojej sytuacji rynkowej. Jednak warto zwrócić uwagę, że często konkurenci znajdują się w zbliżonej sytuacji do przedsiębiorstw wypełniających swoje zobowiązania informacyjne, ale konkurenci ci nie cieszą się takim uznaniem i zaufaniem wśród inwestorów [Droga na giełdę... 2008, s. 52-53].

$\mathrm{Z}$ wprowadzeniem spółki na giełdę wiąże się ryzyko utraty nad nią kontroli. Związane jest ono $\mathrm{z}$ brakiem ograniczeń w zawieraniu transakcji giełdowych i z dużą rotacją akcjonariuszy. W ten sposób w ich gronie mogą pojawić się inwestorzy, których celem jest przejęcie kontroli nad przedsiębiorstwem. Sytuacji takiej można jednak zapobiec poprzez stworzenie oferty sprzedaży w taki sposób, który zapewni możliwie największe rozproszenie akcji i nieotrzymanie ich przez inwestorów, którzy mogą dążyć do przejęcia podmiotu. Przejęcia tego typu utrudniają także przepisy antymonopolowe i ustawa o ofercie publicznej, które zobowiązują do ujawniania posiadanych udziałów po przekroczeniu określonych progów [Droga na giełdę... 2008, s. 54]. 
Wprowadzeniu spółki na giełdę towarzyszy również ryzyko niepowodzenia emisji akcji ${ }^{5}$. Wśród najczęściej wymienianych przyczyn jego zaistnienia wymienia się niewystarczającą podaż kapitału na rynku wśród potencjalnych inwestorów, niezadowalające działania promocyjne, a także nieodpowiedni moment na giełdzie, w którym przedsiębiorstwo zadebiutowało. Negatywny wpływ wymienionych czynników można jednak wyeliminować lub znacząco go ograniczyć. Właściwie zaplanowany proces upublicznienia spółki zwiększa szanse na jej korzystne uplasowanie na giełdzie.

\section{Tendencje na pierwotnym rynku akcji na Giełdzie Papierów Wartościowych w Warszawie}

Tendencje na rynku emisji pierwotnych mogą być oceniane na podstawie następujących kryteriów: rodowodu spółek debiutujących, zależności od indeksu WIG, przyrostu kapitalizacji giełdy, liczby wycofań spółek z giełdy, przyrostu liczby rachunków inwestycyjnych, PKB.

Giełda Papierów Wartościowych w Warszawie została reaktywowana w 1991 r. W pierwszym roku jej funkcjonowania na parkiet wprowadzono 9 przedsiębiorstw, przy czym wszystkie należały do Skarbu Państwa. Na rys. 1 przedstawiono rodowód spółek debiutujących na giełdzie w latach 1991-2012.

Oferty Skarbu Państwa odegrały kluczową rolę w powstaniu i początkowym rozwoju rynku kapitałowego w Polsce. W latach 1991-1994 przedsiębiorstwa o takim rodowodzie stanowiły większość debiutujących podmiotów. Od 1998 r. dużą rolę w rozwoju rynku giełdowego zaczęły pełnić przedsiębiorstwa wywodzące się z sektora prywatnego. W 1997 r. po raz pierwszy zaczęto notować spółki parterowe programu NFI. Znaczny spadek liczby debiutów rozpoczął się w 1999 r. i trwał do 2003 r., a został wywołany załamaniem rynku związanym ze spółkami informatycznymi, a także ogólną bessą występującą na rynku w tym okresie. Natomiast w związku z akcesją Polski do Unii Europejskiej w 2004 r. nastąpiło ożywienie na Giełdzie Papierów Wartościowych w Warszawie i znaczny wzrost liczby debiutów.

Na rys. 2 przedstawiono zależność pomiędzy liczbą debiutów a stopą zwrotu WIG. Analizując wspomniany wykres, można wyciągnąć wniosek, że zmiany stóp zwrotu WIG pociągały za sobą zbliżone zmiany w liczbie debiutów. Wysokie stopy zwrotu osiągane na giełdzie są czynnikiem zachęcającym do przeprowadzenia emisji pierwotnej. Dobra koniunktura zwiększa bowiem prawdopodobień-

${ }^{5}$ Za niepowodzenie należy uznać niezgromadzenie zakładanej ilości kapitału z emisji akcji oraz brak zainteresowania emisją akcji wśród akcjonariuszy i drobnych inwestorów. 


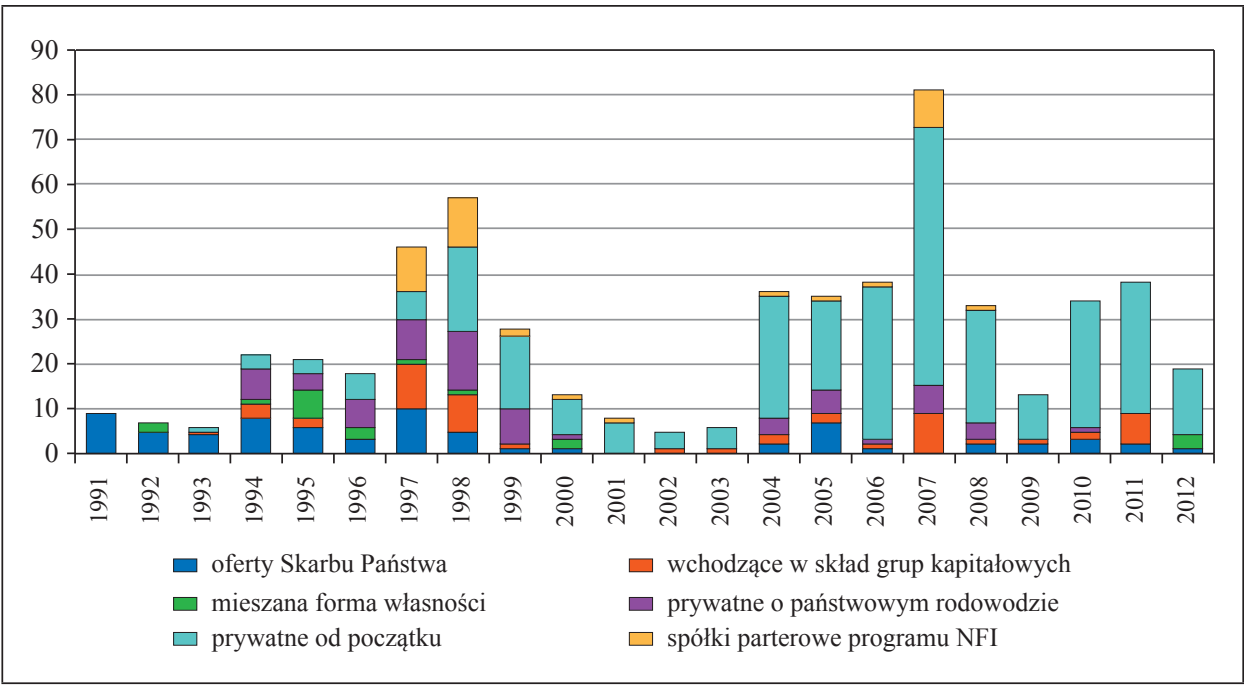

Rys. 1. Rodowód spółek debiutujących na giełdzie w latach 1991-2012 (liczba spółek) Źródło: opracowanie własne na podstawie: [Dane statystyczne... 2013].

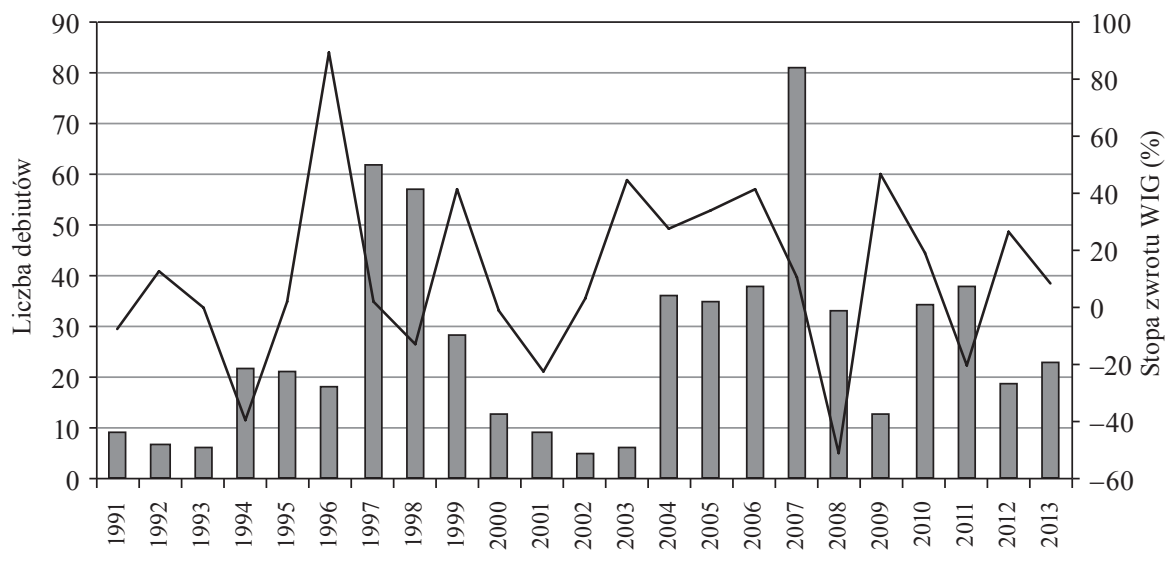

liczba debiutów

— stopa zwrotu WIG (\%)

Rys. 2. Zależność pomiędzy liczbą debiutów spółek a stopą zwrotu WIG w latach 1991-2013

Źródło: opracowanie własne na podstawie: danych Giełdy Papierów Wartościowych w Warszawie oraz [Dane statystyczne... 2013]. 
stwo osiągnięcia sukcesu na rynku IPO, co jest znacznie trudniejsze w okresie obserwowanych spadków na giełdzie.

Na rys. 3 przedstawiono relacje pomiędzy przyrostem kapitalizacji giełdy a liczbą debiutów w latach 1991-2013. W poszczególnych latach funkcjonowania giełdy systematycznie zwiększała się liczba notowanych przedsiębiorstw, a wraz z nią kapitalizacja. Zaobserwować jednak można, że ujemny przyrost kapitalizacji giełdy, który wystąpił w latach 2001, 2008 i 2011 pociągnął za sobą w następnym roku duży spadek w liczbie emisji pierwotnych. Wyjątkowo w 2007 r. na giełdzie debiutowało 81 spółek, a przyrost kapitalizacji osiągnął wartość $444348 \mathrm{mln}$ zł. Był to wzrost kapitalizacji o ok. 70\% w stosunku do roku poprzedniego. Za zjawisko to odpowiadały spółki z branż deweloperskiej i budowlanej, które w tym okresie rozwijały się bardzo dynamicznie. Oferty publiczne przedsiębiorstw z tych branż stanowiły ponad połowę wartości emisji pierwotnych tego roku [Droga na giełdę... 2008, s. 35].

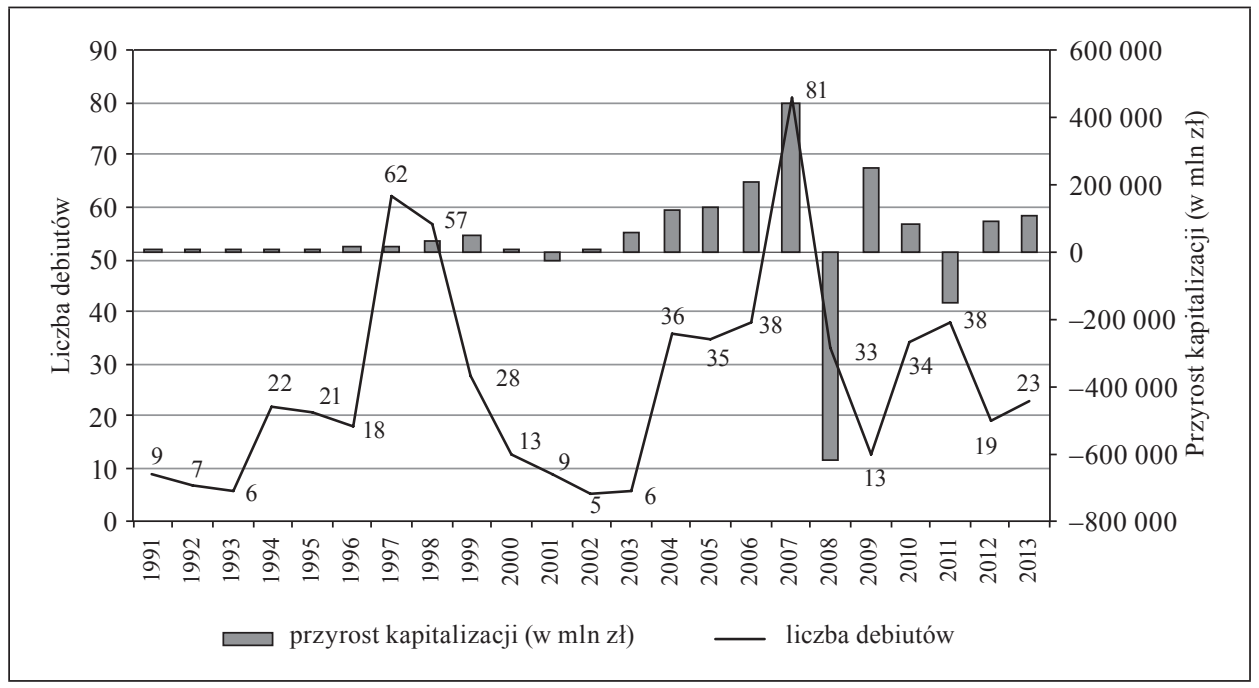

Rys. 3. Relacje pomiędzy przyrostem kapitalizacji giełdy a liczbą debiutów spółek w latach 1991-2013

Źródło: opracowanie własne na podstawie: danych Giełdy Papierów Wartościowych w Warszawie oraz [Dane statystyczne... 2013].

Na rys. 4 przedstawiono liczbę debiutów i wycofań spółek z giełdy w latach 1991-2013. Najsłabszym okresem pod względem liczby przeprowadzonych debiutów były lata 2000-2003, co związane było z występowaniem bessy na rynku, a także załamaniem w branży informatycznej. 
Pierwsze spółki opuściły giełdę w 1997, jednakże największe nasilenie tego zjawiska zaobserwować można w latach 2002-2003. W latach 1997-2011 wśród przyczyn wycofań przedsiębiorstw z giełdy wymienić można: decyzję o wyprowadzeniu z giełdy (29\% przypadków), łączenie się z innym podmiotem (26\%), ogłoszenie upadłości (21\%), a także wykluczenie z giełdy (7\%) [Dudycz 2013, s. 13]. Przejęcia spółek występowały w okresach o dobrej koniunkturze giełdowej, natomiast wyprowadzenia z giełdy zarówno w okresach obserwowanych wzrostów, jak i spadków na giełdzie.

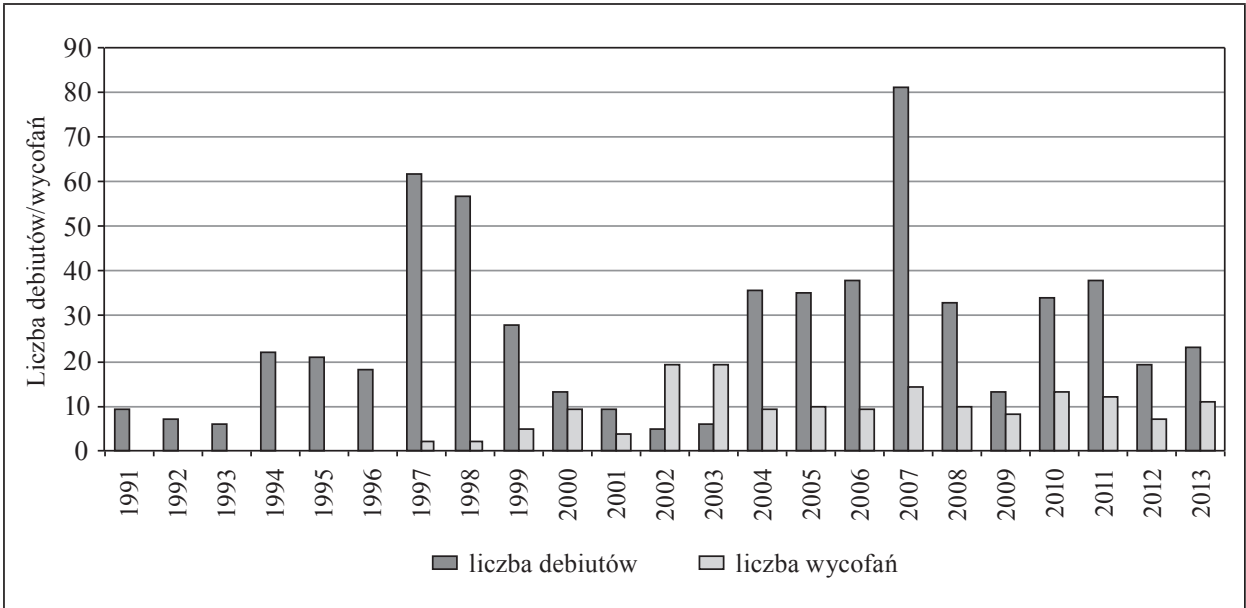

Rys. 4. Liczba debiutów spółek i ich wycofań z giełdy w latach 1991-2013

Źródło: opracowanie własne na podstawie danych Giełdy Papierów Wartościowych w Warszawie.

Zaobserwować można także relację między liczbą debiutów a przyrostem liczby rachunków inwestycyjnych. W początkowych latach funkcjonowania giełdy przyrosty te były związane z debiutami kolejnych spółek. Inwestorzy uczyli się rozumienia zasad i mechanizmów funkcjonowania giełdy. Często występujące niedoszacowania cen emisyjnych akcji pierwotnych dodatkowo zachęcały do aktywności inwestycyjnej. Ponadto znaczenie poszczególnych grup inwestorów zmieniało się w kolejnych latach funkcjonowania giełdy. Powstanie OFE, przygotowania do członkostwa w Unii Europejskiej i przystąpienie do niej spowodowały wzrost znaczenia inwestorów krajowych instytucjonalnych. Zaangażowanie inwestorów indywidualnych wzrasta najczęściej natomiast w latach, w których odnotowuje się wzrost stopy zwrotu WIG20, a spada wraz ze spadkami tego indeksu. Inwestorzy ci chętnie kupują akcje podczas dobrej koniunktury giełdowej, licząc na zyski, a wycofują się z inwestycji w okresach spadków. 


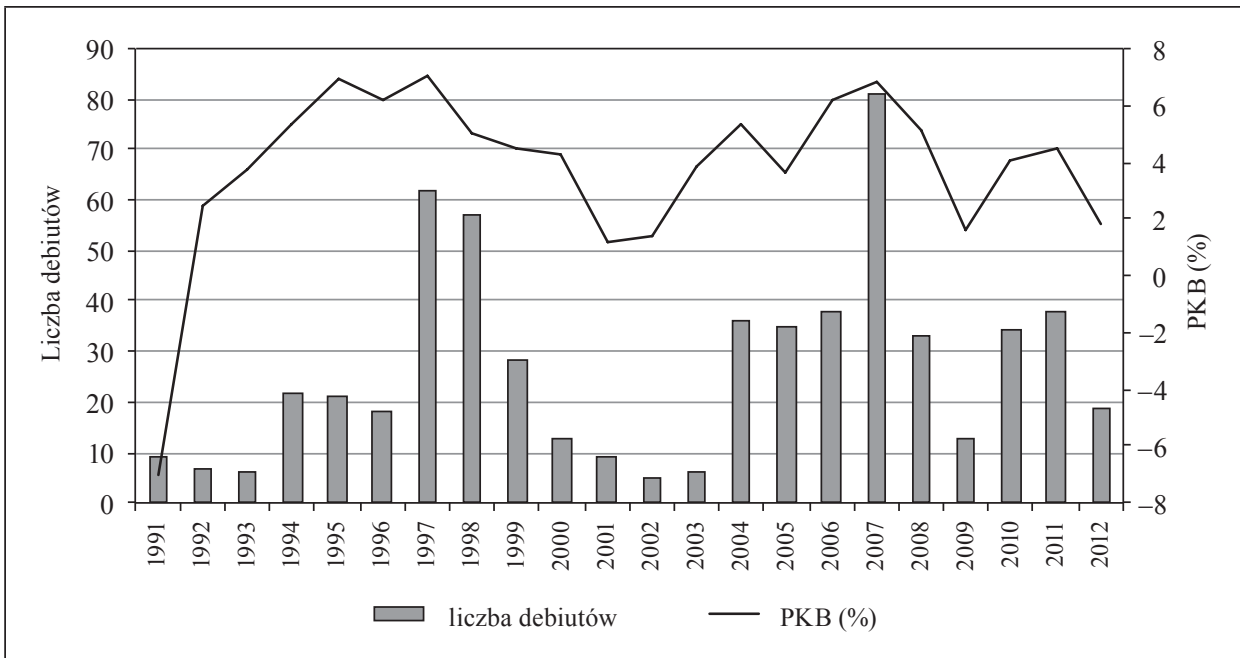

Rys. 5. Relacja pomiędzy liczbą debiutów spółek a PKB w latach 1991-2012 Źródło: opracowanie własne na podstawie: [Dane statystyczne... 2013] i danych World Data Bank.

Na rys. 5 przedstawiono relację pomiędzy liczbą debiutów a PKB. Od 1994 r. zmiany w liczbie debiutów w poszczególnych latach zbliżone są do zmian PKB. Zjawisko to potwierdza, że spółki wprowadzane są na giełdę w okresach dobrej koniunktury gospodarczej i giełdowej, natomiast unika się przeprowadzania debiutów w latach, w których sytuacja ulega pogorszeniu.

\section{Podsumowanie}

Podejmując decyzję o emisji pierwotnej akcji, kierownictwo przedsiębiorstwa powinno rozważyć korzyści i koszty z tym związane. W niniejszym artykule determinanty rozwoju rynku emisji pierwotnych podzielono na te związane z funkcjonowaniem spółki oraz na te związane z jej otoczeniem. Pierwsza grupa tych czynników może być traktowana jako wyznacznik szans i zagrożeń dla rozwoju przedsiębiorstwa, natomiast drugą tworzą zmienne, które są od niego niezależne.

W pracy zbadano również tendencje występujące na pierwotnym rynku emisji akcji na Giełdzie Papierów Wartościowych w Warszawie. Przeprowadzone analizy wykazały, że istnieje zależność pomiędzy zmianą stopy zwrotu indeksu WIG, przyrostu kapitalizacji giełdy, liczbą wycofań spółek z giełdy, przyrostem liczby rachunków inwestycyjnych, PKB a liczbą debiutów w poszczególnych latach. 


\section{Literatura}

Czerwonka M., Rzeszutek M. [2012], Przejawy i uwarunkowania różnic międzypłciowych $w$ zachowaniach inwestycyjnych z punktu widzenia finansów behawioralnych, „Studia i Prace Kolegium Zarządzania i Finansów”, nr 122.

Dane statystyczne za rok 2001 [2002], Rocznik Giełdowy 2002, Giełda Papierów Wartościowych w Warszawie, Warszawa.

Dane statystyczne za rok 2002 [2003], Rocznik Giełdowy 2003, Giełda Papierów Wartościowych w Warszawie, Warszawa.

Dane statystyczne za rok 2007 [2008], Rocznik Giełdowy 2008, Giełda Papierów Wartościowych w Warszawie, Warszawa.

Dane statystyczne za rok 2012 [2013], Rocznik Giełdowy 2013, Giełda Papierów Wartościowych w Warszawie, Warszawa.

Droga na giełdę. Jak przygotować spółkę do emisji publicznej [2008], praca zbiorowa ekspertów BDO, Difin, Warszawa.

Dudycz T. [2013], Działalność inwestycyjna spółek debiutujących na Giełdzie Papierów Wartościowych w Warszawie, Oficyna Wydawnicza Politechniki Wrocławskiej, Wrocław.

Duszek B. [2010], Jak pozyskać kapitał z rynków giełdowych? Przewodnik dla potencjalnych emitentów, Giełda Papierów Wartościowych w Warszawie, Warszawa.

Fiszeder P., Rowiński S. [2012], Modelowanie zależności pomiędzy wybranymi procesami makroekonomicznymi a warszawskim indeksem giełdowym, „Ekonomia i Prawo”, t. X, nr 3, http://dx.doi.org/10.12775/eip.2012.029.

Gackowski T. [2013], Jak badać komunikacje giełdowa?? Perspektywa behawioralno-medioznawcza [w:] Nowe media. Wyzwania i ograniczenia, red. T. Gackowski, Instytut Dziennikarstwa Uniwersytetu Warszawskiego, Warszawa.

Migracja kapitału w globalnej gospodarce [2009], red. A. Szablewski, Difin, Warszawa.

Nawrot W. [2006], Emisja akcji w Polsce w nowej europejskiej perspektywie. Jednolity rynek papierów wartościowych $w$ Unii Europejskiej, Wydawnictwa Fachowe CeDeWu, Warszawa.

Ostrowska E. [2014], Portfel inwestycyjny klasyczny i alternatywny. Metody oceny, wyd. 2, C.H. Beck, Warszawa.

Samuelson P. A., Nordhaus W. D. [2004], Ekonomia, t. 2, wyd. 2, Wydawnictwo Naukowe PWN, Warszawa.

Siwek P. [2005], Praktyka pierwszych ofert publicznych w Polsce, Wydawnictwa Fachowe CeDeWu, Warszawa.

Stąpała J. [2012], Tempo zmian koniunktury gospodarczej i giełdowej w Polsce w latach 1998-2011, ,Economic Studies (Studia Ekonomiczne)”, nr 3.

Strategies for Going Public: The Changing Landscape for IPOs [2012], Deloitte.

Ustawa z dnia 29 lipca 2005 r. o ofercie publicznej i warunkach wprowadzania instrumentów finansowych do zorganizowanego systemu obrotu oraz o spółkach publicznych, Dz.U. z 26.11.2013 r., poz. 1382. 


\section{Determinants of the Development of the Initial Public Offerings Market on the Warsaw Stock Exchange}

The article defines the term "initial public offerings", and identifies and classifies the determinants of the development of the initial public offerings market on the Warsaw Stock Exchange. The determinants are divided into those associated with how companies function and those related to the environment. We analyse trends in the IPO market on the basis of these criteria: the origin of the companies debuting on the market, their dependence on the WIG index, the increase in capitalisation, the number of withdrawals of companies on the stock exchange, the increase in the number of investment accounts, and GDP.

Keywords: initial public offerings, IPO, exchange, debut. 